\title{
Race, School Integration, and Friendship Segregation in America ${ }^{1}$
}

\author{
James Moody \\ Ohio State University
}

\begin{abstract}
Integrated schools may still be substantively segregated if friendships fall within race. Drawing on contact theory, this study tests whether school organization affects friendship segregation in a national sample of adolescent friendship networks. The results show that friendship segregation peaks in moderately heterogeneous schools but declines at the highest heterogeneity levels. As suggested by contact theory, in schools where extracurricular activities are integrated, grades tightly bound friendship, and races mix within tracks, friendship segregation is less pronounced. The generally positive relation between heterogeneity and friendship segregation suggests that integration strategies built on concentrating minorities in large schools may accentuate friendship segregation.
\end{abstract}

\section{INTRODUCTION}

In Brown v. Board of Education (1954), the Supreme Court ruled that schools could not legally separate students by race, officially asserting that our society should be race-blind. If schools are blind to race, then school racial distributions should reflect the distribution of race in the community. At the heart of Brown was the recognition that separate could never be equal, in part because the social relations formed in school are an essential part of the educational process. Subsequently, both legal and scholarly attention has largely focused on the distribution of race within schools. While racially heterogeneous schools may be formally integrated, they are substantively segregated if students interact most often with others of

\footnotetext{
${ }^{1}$ Funding for work on this article came from the National Longitudinal Study of Adolescent Health (Add Health). Thanks to Peter S. Bearman, Lisa A. Keister, Martina Morris, David Jacobs, Doug Downey, Elizabeth Cooksey, Susanne Bunn, and Jill Burkart for comments on earlier drafts of this article. Special thanks to the $A J S$ reviewers, who provided helpful and extensive comments on this article. Direct correspondence to James Moody, 372 Bricker Hall, Department of Sociology, Ohio State University, Columbus, Ohio 43210. E-mail: Moody.77@osu.edu

(C) 2001 by The University of Chicago. All rights reserved. 0002-9602/2001/10703-0004\$10.00
}

AJS Volume 107 Number 3 (November 2001): 679-716 
American Journal of Sociology

their own race. The lived experience of students in such settings is of racial division, not integration.

Finding friendship segregation in heterogeneous settings should not be surprising for at least three reasons. First, a large body of literature on homophily suggests that people prefer friends who are like themselves along multiple dimensions (Hallinan and Williams 1989; Kandel 1978; McPherson and Smith-Lovin 1987; Tuma and Hallinan 1979). An individual-level preference for similar friends suggests that, all else equal, when people have the opportunity to choose relations within their own race they will. Second, while schools may be integrated at the population level, internally they may still be racially divided. Organizational factors such as tracks and extracurricular activities may decrease opportunities for cross-race contact by resegregating an otherwise-integrated school(Epstein 1985). Finally, work on ethnic threat and competition has consistently found a nonlinear relation between heterogeneity and racial relations (Blalock 1967; Smith 1981). Race becomes most salient when heterogeneity is in the middle ranges, such that minorities could potentially threaten the dominant position of the majority. If a similar dynamic is active in schools, then we would expect to see higher friendship segregation in schools where heterogeneity is moderately high.

Empirically, we observe very different levels of friendship segregation across similarly heterogeneous settings. In some heterogeneous schools, student bodies mix informally; while in others, majority and minority students rarely call each other friends. Since friendship segregation results from the multilevel influences of mixing opportunity and individual preference, we should be able to account for variation in friendship segregation across settings by identifying organizational features of schools that bring students of different races together in ways that foster friendship. School organizational factors affect both the probability of contact (Feld 1981; Feld and Carter 1998; Hallinan and Williams 1989) and the social significance of interaction (Allport 1954; Schofield 1979, 1991). Academic tracking, for example, simultaneously separates students and creates a status differential between students in academic tracks (often white) and students in nonacademic tracks (often nonwhite) (Epstein 1985; Longshore and Prager 1985; Schofield 1991). Extracurricular activities, however, often bring students together in informal cooperative interaction. If extracurricular activities also mix students by race, then such activities could increase the overall level of interracial friendship in a school.

One approach to structuring schools for racial integration is to maximize the potential number of cross-race friendships and hope that maximizing friendship opportunity simultaneously minimizes friendship segregation (Feld and Carter 1998). Paradoxically, under most circumstances, the maximum number of potential interracial ties in a school system can be 
achieved by concentrating minority students within one large school instead of distributing races proportionately across all schools. ${ }^{2}$ This follows since the same minority student creates many more potential cross-race ties in a large school than in a small school. This approach to friendship integration may fail, however, because it ignores both the quality of interaction within the school and the increased opportunity for self-segregation. If concentration simultaneously provides increased opportunity for same-race friendship formation, homophily predicts that people will concentrate friendship within their own race. Since people have a finite capacity for relationships (van der Poel 1993; Zeggelink 1993), in a school where there are many minority students, minority students may be able to find their desired number of friends within the minority friendship pool. If so, then the revealed preference for same-race friendship increases, and concentrating minority students within a large setting may, in fact, exacerbate friendship segregation.

The purpose of this article is to examine the school-level relation between formal integration, as indicated by racial heterogeneity, and substantive integration, as indicated by the pattern of interracial friendships. Previous work has been based almost entirely on regional samples of young children or small pair-level subsamples of larger networks (Epstein 1985; Hallinan and Smith 1985; Hallinan and Teixeira 1987; Hallinan and Williams 1989; Patchen 1982; Schofield 1979). While consistently showing that race is salient for friendship formation, we have been unable to examine the patterns in a national context and link these patterns to school organization. In this article, I extend previous work on race and friendship choice by using a national sample of middle and high school students based on data from the National Longitudinal Study of Adolescent Health (Add Health). Building on Allport's (1954) insight that status equality is essential for positive intergroup relations, and work on extracurricular education that shows schools can control the mixing patterns of students through extracurricular activities (Quiroz, Gonzalez, and Frank 1996), I identify organizational characteristics of schools that facilitate interracial friendship.

\section{FRIENDSHIP SEGREGATION}

Friendship segregation is the correspondence between an attribute that defines a class of people and friendship choice. Following Freeman (1972, p. 414), I argue that, "classes of persons are segregated to the degree that

\footnotetext{
${ }^{2}$ At issue here is the number of pairs, not the number of people with a cross-race friendship tie.
} 


\section{American Journal of Sociology}

their social relations are restricted to members of their own class and do not 'cross over' to members of the other classes" (see also Granovetter 1986). In a perfectly integrated school, the probability of observing a crossrace friendship would be the same as the school racial heterogeneity. Substantively, this conception of segregation matches that implied in the Brown (1954) decision: a setting is integrated when race is not salient for social relations.

As an intuitive example of how schools can differ in the level of friendship segregation, compare "Countryside High School," presented in figure 1, to "Mountain Middle School," presented in figure 2. ${ }^{3}$ Countryside is a racially heterogeneous school, but the friendship patterns suggest that race is particularly salient. Within this school, there are two structurally distinct communities: one white and the other nonwhite. In Mountain Middle School, on the other hand, students of different races mix often and race is not salient for friendship choice. While there is a clear structural division between two groups, this division is based on grade, not race.

Countryside High and Mountain Middle School are extreme examples of the variation in friendship segregation. What accounts for this difference? As will become clear, while friendship segregation is a common outcome in racially heterogeneous schools, it need not be. The ways that schools organize student mixing has a strong effect on interracial friendship patterns.

\section{RACIAL-MIXING THEORIES}

Understanding the observed difference in racial mixing across settings like Countryside High and Mountain Middle School requires carefully distinguishing between student behavior and school organization. At the behavior level, homophily and social balance are tendencies known to affect friendship structure. At the school level, student mixing opportunity, school policy, and cultural setting likely determine friendship segregation. From a policy standpoint, school administrators have more control over organizational features than over student behavior. As such, while I iden-

\footnotetext{
${ }^{3}$ Names used in this article are pseudonyms. In fig. 2, points represent students and lines are friendship nominations. In the figure (but not the analyses that follow), the direction of the nomination is ignored. The graphs use a spring-embedder algorithm (PAJEK, ver. 21, written by Vladimir Batagelj and Andrej Mrvar [1999] and distributed on-line at http://vlado.fmf.uni-lj.si/pub/networks/pajek/default.html), which minimizes the distance between connected points and maximizes the distance between disconnected points. Isolates cannot be substantively placed in such a figure, and I have not included them. For clarity, points are colored as simply white or nonwhite. In the analyses, a more complete specification of race and ethnicity is used.
} 
Friendship Segregation

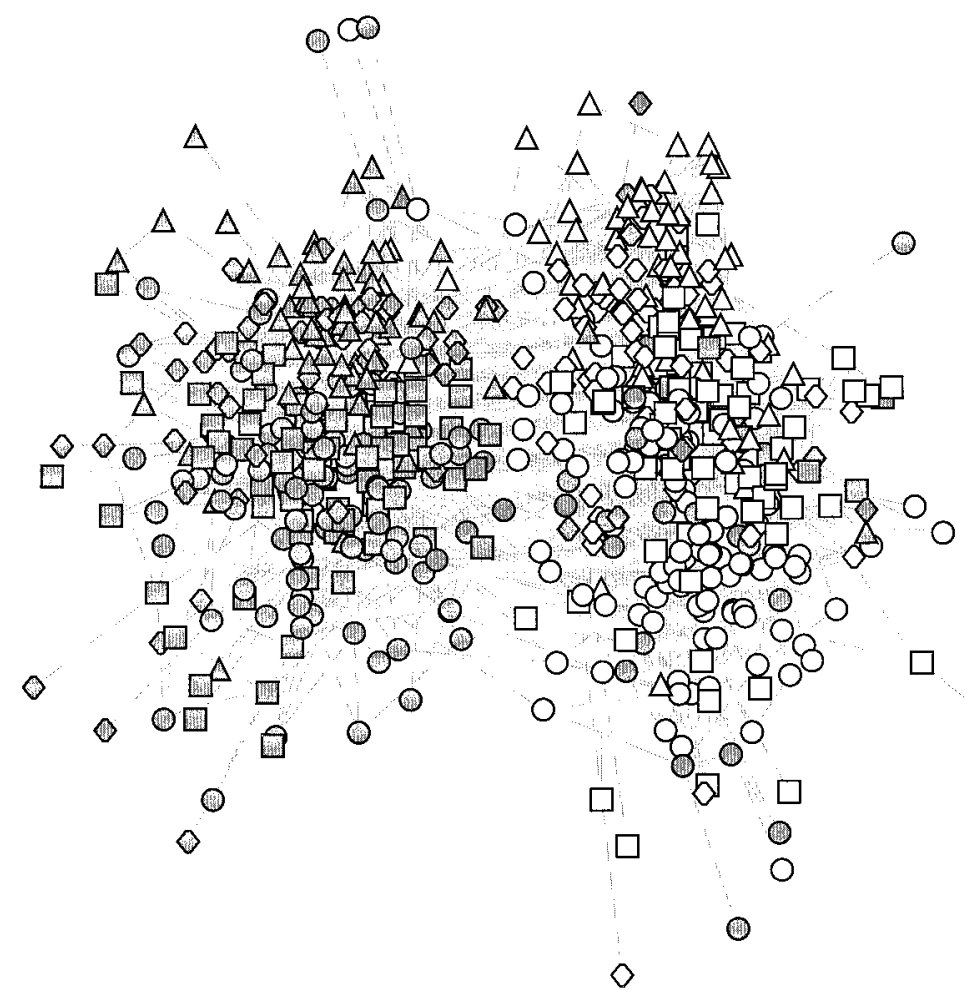

FIG. 1.-Friendship relations in "Countryside High School" by race and grade. Shaded figures represent nonwhite students. Circles $=$ ninth graders, squares $=$ tenth graders, hexagons $=$ eleventh graders, and triangles $=$ twelfth graders.

tify the individual-level factors that might affect friendship segregation (which I use to specify a school-level measure of net friendship segregation), most of the following identifies organizational features that administrators can manipulate to increase racial integration.

Homophily and Social Balance

The starting point for any individual-level model of friendship formation is the well-known preference for similarity in social relations (Billy, Rodgers, and Udry 1984; Blau 1977; Coleman 1961; Kandel 1978; McPherson and Smith-Lovin 1987; St. John and Lewis 1975; Tuma and Hallinan 1979; Verbrugge 1977). Since homophily has been identified on multiple dimensions, an observed preference for same-race friends may be spuriously related to other important friendship dimensions, such as socio- 
American Journal of Sociology

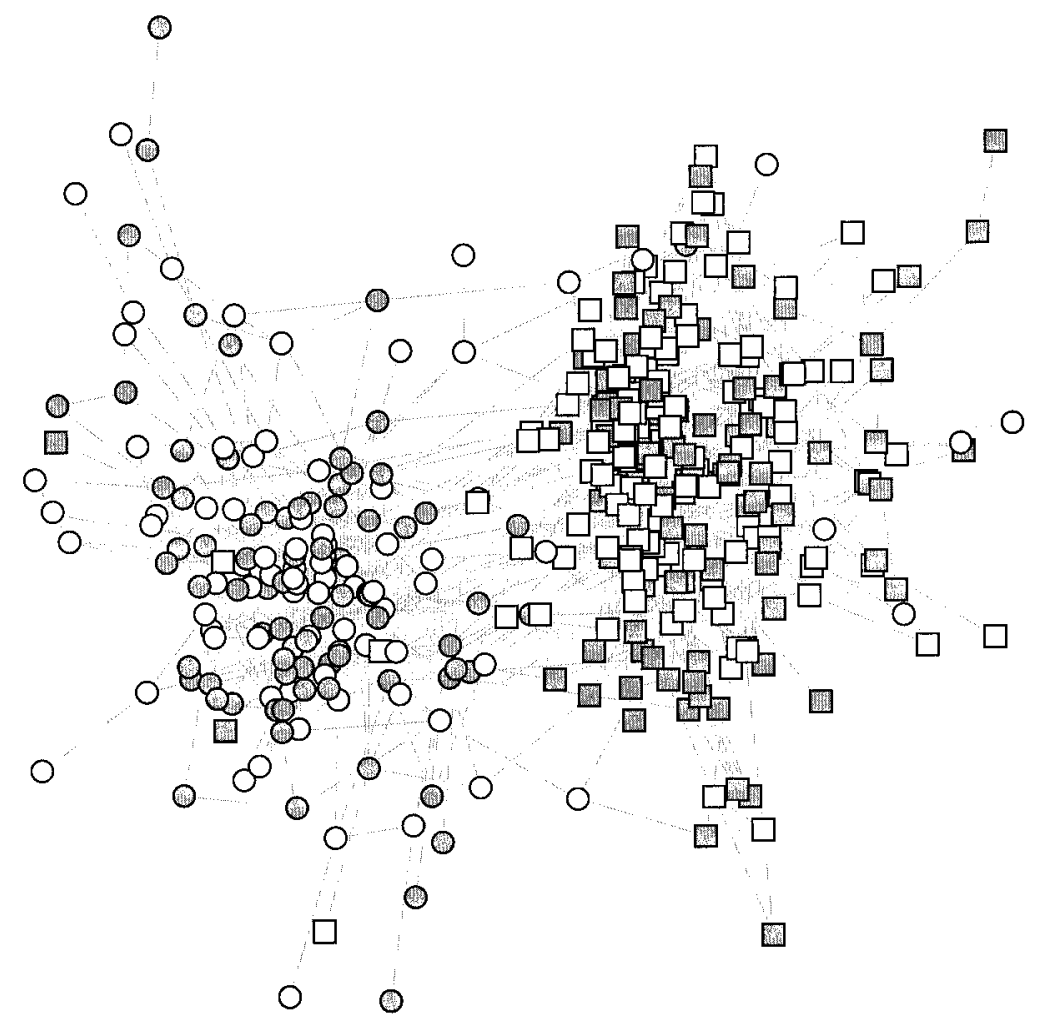

FIG. 2.-Friendship relations in "Mountain Middle School" by race and grade. Shaded figures represent nonwhite students. Circles $=$ seventh graders and squares $=$ eighth graders.

economic status. Any attempt to model friendship segregation needs to identify features that might lead to friendships based on nonracial similarity. Previous work suggests that friendship pairs tend to be similar with respect to socioeconomic status, popularity, school performance, gender, and delinquent behavior (Billy et al. 1984; Cohen 1977; Cohen 1983; Coleman 1961; Kandel 1978; Tuma and Hallinan 1979).

While most work on homophily focuses on attribute similarity, it can been shown that homophily is a specific form of social balance (Davis 1963). The more general effect of social balance on relational structure may also explain why race is more or less salient in a given setting. Simply put, balance theory predicts that a friend of a friend will be a friend, as enmity among one's friends leads to strain and is avoided (Heider 1946; Davis 1963; Holland and Leinhardt 1971; Davis and Leinhardt 1972; Johnsen 1985). Empirical support for balanced friendship networks has 
been strong, with most networks exhibiting greater than expected levels of social balance (Hallinan and Kubitschek 1990; Doreian et al. 1996; Davis and Leinhardt 1972; Hallinan 1978). ${ }^{4}$ With respect to race, social balance can magnify racial friendship patterns. If race is an important attribute for initial friendship choice, then social balance will magnify the importance of race by building cliques around an initial race-based friendship. For the same reasons, an initial cross-race friendship ought to generate cross-race friendships among friends of friends. Thus, regardless of the starting point, social balance crystallizes friendship patterns around race. Any attempt to identify the extent of racial friendship segregation needs to distinguish balance effects from same-race preference effects.

\section{Focal Organization and Population Structure}

At the organizational level, an important factor for friendship is simple mixing opportunity (Blau 1977; Feld 1981; Hallinan 1982; Hallinan and Williams 1989; Newcomb 1961; Coleman 1961). Organizational features that group people into classes (foci) make it much more likely that particular types of people meet (Feld 1981). Academic tracking, grade, and extracurricular activities are the primary foci that structure meeting opportunity in schools. If student assignment to an academic track is correlated with race, then track assignment can resegregate an integrated school by limiting cross-race exposure. The level of cross-race exposure is maximized when all students are in one track (either all academic or all nonacademic) and decreases as tracks fragment the student body, resulting in a U-shaped relation between exposure and the proportion of students in nonacademic tracks. ${ }^{5}$ If students are assigned to tracks randomly, this $U$-shaped curve will be symmetric, reaching a minimum when students are evenly split between academic and nonacademic tracks. When schools disproportionately assign minority students to nonacademic tracks, however, the shape of the exposure curve is skewed. Holding constant the proportion of minorities in the school, the minimum point of the exposure curve shifts left in proportion to the bias with which minority students are assigned to nonacademic tracks. Under these conditions, cross-race exposure increases with the proportion of students enrolled in nonacademic tracks.

While tight mixing within tracks may increase friendship segregation, mixing within grade may increase interracial friendships. Only rarely do

\footnotetext{
${ }^{4}$ As measured through the number of transitive triads in the network. A triad is transitive if, whenever $i$ nominates $j$, and $j$ nominates $k, i$ also nominates $k$.

${ }^{5}$ The logic here follows that of Feld and Carter (1998). Thanks to an AJS reviewer for pointing out the complexity of track assignments for interracial contact.
} 
American Journal of Sociology

students in one grade mingle with students in another, and administrators can control the extent of cross-grade exposure through the academic schedule. If grades tightly constrain friendship opportunity, then every person's friendship choice is limited to the set of all people in their grade and the ability to further select friends on other dimensions (such as race or economic standing) is lowered. The relative importance of grade segregation over race segregation is suggested by figures 1 and 2. In Countryside High School, race trumps grade as the primary division evident in the network, with grades ordered (somewhat) within the race clusters. An opposite pattern is apparent in Mountain Middle School, where the primary division is between seventh and eighth graders. As such, I would expect racial friendship segregation to be lower in settings where friendships are tightly bound within grades. If this is true, then decreasing between-grade mixing is one lever that school administrators can use to promote racial integration.

Finally, extracurricular activities such as clubs, sports, and student service organizations form important school foci (Holland and Andre 1987; Quiroz et al. 1996). Extracurricular activities provide informal and often enjoyable mixing opportunities in settings of relative equality (everyone is a member of the same team) that foster friendship. If students of multiple races meet within extracurricular activities, friendship segregation ought to decrease. Administratively, schools can control the mixing opportunities of students, especially through extracurricular activities. In a multiple investigative, longitudinal ethnography of a midwestern city school, Quiroz et al. (1996) showed that schools used both formal (e.g., grade eligibility or attendance requirements) and informal (e.g., recruitment techniques) means to select students into extracurricular activities. In general, their work shows that administrators can control the mix of students involved in extracurricular activities (see also Crain 1981; Slavin and Madden 1979). In schools committed to racial integration, such control could be used to support an integrative school climate by developing mixed-race activities for student interaction.

Much of the work on interracial contact starts with Blau's macrostructural theory of intergroup relations (Blau 1977; Blau and Schwartz 1984; Fararo and Skvoretz 1987; McPherson and Smith-Lovin 1987; Rytina and Morgan 1982). Blau's work points to three important aspects of the population structure for intergroup contact. First, as in-group size increases, out-group contact decreases. ${ }^{6}$ Second, Blau shows that as heterogeneity increases, the probability of intergroup contact increases. Third, the distribution of characteristics in the population constrains con-

\footnotetext{
${ }^{6}$ Blau's work is based on symmetic relations and has focused almost entirely on the simplified assumption that every person has the same number of ties.
} 
tact opportunity by compressing the dimensions of social space. When SES and race are highly correlated, for example, choosing relations based on SES constrains one's ability to choose on race. Identifying the extent to which races interact informally requires accounting for this characteristic of the population structure.

\section{Contact Theory}

Both Blau (1977) and Feld (1981) based their theories on a random-mixing assumption: the greater the opportunity for people to meet, the greater the likelihood that relationships form. Contact theory (Allport 1954) situates interracial mixing within a setting's status hierarchy, identifying three characteristics that explain why contact leads to friendship in some settings and conflict in others. The first characteristic is the status equality of the participants. If the setting is structured such that positional hierarchy is correlated with race, then interracial friendships are unlikely and stereotypes about inherent group differences will be magnified (Hewstone and Brown 1986). Second, cooperative interdependence is expected to foster intergroup relations (Bossert 1988-89; Johnson and Johnson 1992). The most effective groups are those organized around a common goal that cannot be achieved independently (Schofield 1995). Team sports, music and drama, newspapers, or student government are all examples of school activities that involve students working for collective ends. According to contact theory, racial mixing in such groups ought to promote interracial friendships.

A third element of contact theory is the explicit support for interracial mixing from recognized authorities in the setting. In schools where teachers, coaches, and administrators express favor for interracial contact and set clear expectations for cross-race behavior, interracial friendships should increase (Schofield 1995; Patchen 1982). We are likely to find these cooperative school climates (Stockard and Mayberry 1992) in settings where extracurricular activities are integrated or where the faculty is racially mixed. Given the ability of administrators to select students into extracurricular activities (Quiroz et al. 1996), a racially integrated extracurricula suggests that schools may be attempting to promote interracial mixing. If contact theory is correct, then as cross-race exposure through extracurricular activity increases, we should see lower levels of racial friendship segregation.

\section{School Administrative Practices}

The features outlined above should affect racial mixing in any organization. In addition to these general factors, particular school features are 
American Journal of Sociology

likely important for how races mix within school settings. First, school admission policies and school type affect the distribution of race and might account for any observed relation between heterogeneity and friendship segregation. Racial heterogeneity is sometimes achieved by busing students from one geographic area to another. This practice is often controversial and may lead to a charged racial environment. If busing increases both heterogeneity and racial hostility, then the observed relation between heterogeneity and friendship segregation could be spurious on busing.

Public and private schools differ significantly with respect to racial segregation and organizational practices, which may affect the salience of race for friendship choice (Coleman, Hoffer, and Kilgore 1982; Lee et al. 1998; Sandy 1989; Taueber and James 1982). First, private schools often select students from richer economic strata than public schools, and ethnographic work suggests that the class differences are reflected in informal school relations (Willis 1977; MacLeod 1995). If racial tension is greater in poor and working-class settings, then public schools may have greater race-based friendship segregation than private schools. Second, private schools differ in the extent and quality of academic tracking (Lee et al. 1998). Third, some have argued that private schools have a greater sense of community that should lead to a greater level of friendship integration (Coleman and Hoffer 1987). Similar differences may follow from urban location. Because resources affect the ability of schools to promote interracial friendship, and since suburban schools tend to be better endowed economically, rural and urban schools might have higher friendship segregation levels than suburban schools. However, students from urban settings are often exposed to many types of people, have had longer experience with racial mixing, and thus may have lower friendship segregation.

The problem of racial friendship segregation is complex. At the individual level, there is a long history of research demonstrating that people prefer people like themselves. While the individual effects of similarity, balance, and status are important for friendship formation, the structural constraints of population distribution affect one's ability to realize individual preferences. The effect of cross-group exposure is complicated by the situational status and hierarchy of groups within the school, making it unclear whether acquaintance-level, noninteractive exposure will lead to friendship formation. To succeed in meeting the ideal expressed in Brown, the rate of cross-race friendship should equal the opportunity for such contact; however, when race remains salient for friendship formation, schools remain substantively segregated. 
Friendship Segregation

DATA

The Adolescent Health Study

The National Longitudinal Study of Adolescent Health is a longitudinal, school-based survey of adolescents in grades 7-12. Using an implicit stratification procedure, researchers selected a nationally representative sample of all public and private high schools (defined as schools with an eleventh grade) in the United States with a minimum enrollment of 30 students from the Quality Education Database (QED) in April 1994. High schools were systematically selected with probability proportional to enrollment from a list sorted on region (Northeast, Midwest, South, and West), urban location (urban, suburban, rural), school size $(<125,126-350,351-775$, $>776$ ), school type (public, private, parochial), \%white (0, 1-66, 67-93, 94-100), and grade span (k-12, 7-12, 9-12, 10-12). For each of 80 sampling strata, a school or pair of schools spanning grades 7-12 was recruited to participate in the study. Because the design employed systematic sampling on a sorted list, it assured that the sample was representative along the dimensions used to sort the list. In most communities, two schools were recruited: a high school with grades $9-12$ or grades $10-12$, and a middle school with grades $7-8$ or grades $7-9$, respectively. If a high school refused to participate, a replacement school from within the same strata was selected until the cell was filled. This selection procedure resulted in a national sample of 132 schools. Two of the 132 schools do not have sample weights and thus cannot be used to generalize to the nation as a whole, resulting in an effective sample of 130 schools. $^{7}$

In total, 90,118 students completed school interviews, providing global network infomation for each school. Each student received a list of students in their school and its sister school. Students identified up to five

\footnotetext{
${ }^{7}$ For Add Health design details, including discussion of sampling and weighting, see the Add Health Web page at http://www.cpc.unc.edu/projects/addhealth/. Reasons for nonresponse were varied, "Despite our best efforts, approximately $20 \%$ of our initially sampled schools refused to participate. . . . Refusals were a result of idiosyncratic factors that could not be anticipated, including an affair between a principal and teacher, an angry parent heavily connected to an active PTA organization, and an upcoming school board election. The top three reasons for school refusals were (1) potential backlash from communities and fear of parent organizations' negative mobilization given the linkage between the in-school and the more sensitive in-home survey; (2) time away from class instruction; and (3) burden on school personnel" (Bearman et al. 2000). Unfortunately, no quantitative data on nonselected schools is available, making it impossible to statistically compare selected to nonselected schools on characteristics not used to sort the initial sample frame.
} 


\section{American Journal of Sociology}

male and five female (10 total) friends from this roster. ${ }^{8}$ Of the 130 schools originally selected, 112 schools had response rates high enough to provide reliable global network data. In addition to the student surveys, administrative features of the school were coded from interviews with school administrators. While the sample of schools with network data differs slightly from the sample as a whole, sample selectivity appears minor. ${ }^{9}$

\section{MEASURES AND MODEL SPECIFICATION}

Table 1 defines all variables used in the analysis and provides the (weighted) sample means and standard deviations. After describing the measures used in the analyses, I then specify the models.

\section{Dependent Variables}

Gross Friendship Segregation: $\alpha$

Friendship segregation refers to the extent to which race is salient for people's friendship choices. In segregated settings, race determines friendship choice; in integrated settings, race is not relevant. This conception of segregation implies that when schools are integrated, the likelihood of a cross-race friendship tie equals the distribution of cross-race pairs in the school. This conception highlights the relative opportunities people have to make cross-race friendship choices. If people have many oppor-

\footnotetext{
${ }^{8}$ The maximum number of nominations allowed was 10 , but this restriction affected few students. Of all students, $3 \%$ nominated 10 in-school friends, $23 \%$ of all students nominated five in-school male friends, and $25 \%$ of all students named five in-school female friends. Previous research suggests that close friendship groups have about five or six members (Cotterell 1996; Dunphy 1963). Constraining the number of friendship nominations is only problematic if those people who would have been named, if a student had more nomination opportunities, would have differed racially from those already named. The survey asked students to order their friendships. If the likelihood of a cross-race tie is related to friendship order, then limiting nomination numbers may distort the actual degree of racial integration. Across all students, the proportion of same-race ties, by same-sex friendship order was $69 \%, 68 \%, 67 \%, 67 \%$, and $67 \%$ for males, $72 \%, 71 \%, 70 \%, 70 \%$, and $69 \%$ for females. Thus, there appears to be little substantive relation between friendship order and race, so the general patterns of crossrace ties is likely captured with these data.

${ }^{9}$ A comparison of schools with network data to those without network data is presented in table A1 in the appendix. The number of excluded schools is small, and thus statistical comparisons are difficult. Schools without network data are slightly more racially homogeneous, are disproportionately from the west, and tend to use tracking practices somewhat less than the sample as a whole. While sample selectivity in such a situation can never be ruled out entirely (Stolzenberg and Relles 1997; Winship and Mare 1992), the schools used in the network sample are quite similar to those that are not used.
} 
TABLE 1

Descriptive Statistics for VARIAbles Used in the ANALysis

\begin{tabular}{|c|c|c|c|}
\hline Variable & Description & Mean & SD \\
\hline \multicolumn{4}{|l|}{ Dependent variable: } \\
\hline $\begin{array}{l}\text { Same-race friendship } \\
\text { preference } b_{1}\end{array}$ & $\begin{array}{l}\text { The coefficient from in-school dyadic } \\
\text { friendship model; reflects the net prefer- } \\
\text { ence for friendships with people of the } \\
\text { same race or ethnicity }\end{array}$ & .23 & .30 \\
\hline $\begin{array}{l}\text { Log odds of a same-race } \\
\text { friendship nomination } \\
(\alpha)\end{array}$ & $\begin{array}{l}\text { Natural log of the odds that a person will } \\
\text { nominate a friend of their same race rel- } \\
\text { ative to the odds that they will nomi- } \\
\text { nate someone of a different race }\end{array}$ & .51 & .41 \\
\hline \multicolumn{4}{|l|}{ Independent variables: } \\
\hline \multicolumn{4}{|l|}{ Race distribution: } \\
\hline Student heterogeneity & $\begin{array}{l}\text { The probability that any two students cho- } \\
\text { sen at random are of different races }\end{array}$ & .40 & .19 \\
\hline $\begin{array}{l}\text { Race and SES consoli- } \\
\text { dation }\end{array}$ & $\begin{array}{l}\text { The multiple correlation coefficient of SES } \\
\text { regressed on race }\end{array}$ & .22 & .12 \\
\hline \multicolumn{4}{|l|}{ Focal organization: } \\
\hline Tracking & $\begin{array}{l}\text { Proportion of students in a nonacademic } \\
\text { track }\end{array}$ & .64 & .36 \\
\hline Grade segregation & $\begin{array}{l}\text { Extent to which friendships are segregated } \\
\text { by grade, calculated using Freeman's } \\
\text { segregation index, with the network par- } \\
\text { titioned by grade }\end{array}$ & .69 & .12 \\
\hline $\begin{array}{l}\text { Race-based extracurri- } \\
\text { cular mixing }\end{array}$ & $\begin{array}{l}\text { Freeman's segregation index applied to the } \\
\text { joint activity network }(x-100)\end{array}$ & -.78 & 2.1 \\
\hline \multicolumn{4}{|l|}{ School characteristics: } \\
\hline Racial busing & $\begin{array}{l}\text { Indicator for busing students to achieve } \\
\text { racial mixing }\end{array}$ & .04 & .21 \\
\hline Public school & Indicator for being a public school & .83 & .38 \\
\hline Teacher heterogeneity & $\begin{array}{l}\text { The probability that any two teachers in } \\
\text { the school chosen at random are of dif- } \\
\text { ferent races }\end{array}$ & .14 & .17 \\
\hline School SES & $\begin{array}{l}\text { SES is based on the sum of two five-point } \\
\text { ordinal rankings of parent's education } \\
\text { and occupation, which is then averaged } \\
\text { over the school }\end{array}$ & 5.89 & .93 \\
\hline \multicolumn{4}{|l|}{ Control variables: } \\
\hline Out-of-school nominations & $\begin{array}{l}\text { Mean number of ties students send to } \\
\text { friends who are not also members of the } \\
\text { school }\end{array}$ & 1.29 & .46 \\
\hline School network density & $\begin{array}{l}\text { Number of observed ties, relative to the } \\
\text { number of possible ties given maximum } \\
\text { degree }\end{array}$ & .51 & .15 \\
\hline South & Indicator for location in the South & .32 & .47 \\
\hline
\end{tabular}


American Journal of Sociology

TABLE 1 (Continued)

\begin{tabular}{llrr}
\hline \hline \multicolumn{1}{c}{ Variable } & \multicolumn{1}{c}{ Description } & Mean & SD \\
\hline Urban & Indicator for being urban & .22 & .42 \\
Rural & Indicator for being rural & .18 & .39 \\
School size & Number of students in the school, divided & .33 & .37 \\
& by 1,000 & & \\
\hline
\end{tabular}

tunities to form cross-race friendships, but do not avail themselves of those opportunities, then race is clearly significant for friendship choice and the setting is substantively segregated.

While conceptually clear, complications arise when one wants to evaluate the relation between a school's racial distribution and the level of friendship segregation. To measure the relationship between friendship segregation and racial heterogeneity, the measure of friendship segregation must not mechanically depend on the distribution of race in the school (Charles and Grusky 1995). ${ }^{10}$ One measure that is mathematically independent of the distribution of race is the odds ratio $(\alpha)$ of a same-race $\times$ friendship cross-tabulation. Alpha is calculated based on the values in table 2, as $\mathrm{AD} / \mathrm{BC}$, and provides a measure of association that is invariant to multiplicative transformations of the marginals of the mixing table (Mosteller 1968, p. 4). ${ }^{11}$ That is, the number of students in a school of any particular race does not affect the core association between race and friendship underlying the table. This independence is important because any attempt to relate heterogeneity to relational segregation based on a nonindependent measure could generate artifactual results. Alpha is substantively interpretable as the odds ratio of a friendship between members of a same-race dyad relative to friendship in a cross-race dyad. When $\alpha=1$, then the odds of a same-race friendship equal the odds of a crossrace friendship, and the setting is perfectly integrated. As $\alpha$ increases, the relative odds of a same-race friendship increase by a factor of $\alpha$. Since $\alpha$ is scaled from 0 to $\infty$, I use $\ln (\alpha)$, which ranges from $-\infty$ to $+\infty$ in the school-level models below.

\section{Net Friendship Segregation}

While mechanically free of the school's race distribution, $\alpha$ is not an analytically optimal measure for determining the causes of friendship

${ }^{10}$ Charles and Grusky (1995) provide a sex segregation index based on a log multiplicative model of the distribution of sex and occupation. While work extending the general model to more than two categories has begun (Grusky, personal communication), an index for more than two categories is not currently available.

${ }^{11}$ Alternative analyses, using Freeman's segregation index (which is not margin-free), are available from the author. 
Friendship Segregation

TABLE 2

Calculating Relational Segregation

\begin{tabular}{lcc}
\hline \hline & Same-Race Dyad & Cross-Race Dyad \\
\hline Friend $\ldots . .$. & A & B \\
Not friend $\ldots$ & C & D \\
\hline
\end{tabular}

segregation. A preferable measure would be calculated net of the individual-level characteristics that could create a spurious association between race and friendship and thereby overestimate the substantive level of friendship segregation. Additionally, an analytically useful index of friendship segregation should account for random measurement error. One way to account for both random variation and microlevel friendship factors is to develop a statistical model of friendship choice and use the samerace parameter from that model as a measure of net friendship segregation. Based on the $P^{*}$ modeling framework, this approach allows me to identify race-based friendship preference net of characteristics correlated with both race and friendship (Pattison and Wasserman 1999; Wasserman and Pattison 1996; see Frank and Yasumoto [1988] for a similar application in a multilevel context). Additionally, the model accounts for network properties that might distort the importance of race, such as the degree of social balance (transitivity), clustering, and asymmetry in friendship nominations.

The model I use is described in general terms in Lincoln (1984), and specifically for analyzing global networks in a series of papers by Wasserman and Pattison (Wasserman and Pattison 1996; Pattison and Wasserman 1999). ${ }^{12}$ To estimate the model, I first transform the network of $N$ students into the set of $N(N-1)$ ordered dyads. The resulting dyad vector, $Y_{i j}$, equals " 1 " if person $i$ nominates person $j$ as a friend, and " 0 " otherwise. The effect of a structural feature of the network on friendship choice is determined by calculating the difference in the network statistic when the $i j$ relation is forced to be present compared to when the $i j$ relation is forced to be absent. Substantively, this differencing conditions the probability of $Y_{i j}$ on the observed features of the network.

\footnotetext{
${ }^{12}$ According to Wasserman and Pattison (1996), unlike earlier log-linear models of dyads, the $P^{*}$ logit models need not assume that dyads are independent, instead allowing them to be conditionally dependent. The models I use differ slightly from the standard $P^{*}$ model since I do not include individual-level fixed effects (called expansiveness and attractiveness parameters in the $P^{*}$ literature). Including these parameters for each sender and receiver would imply adding $2 N$ additional variables to each model. Given the size of my networks, this would imply estimating models with literally thousands of variables, which is too cumbersome. Instead, I capture expansiveness and attractiveness with sender out-degree and receiver in-degree, respectively.
} 


\section{American Journal of Sociology}

Formally, the model I estimate within schools to generate a net measure of friendship segregation is

$$
\begin{aligned}
\log \left(\frac{p\left(Y_{i j}=1\right)}{p\left(Y_{i j}=0\right)}\right)=b_{0} & +b_{1} \text { samerace }+b_{2-7} N_{i j} \\
& +b_{8} \text { samesex }+b_{9,10} F_{i j} \\
& +b_{11-15} B_{i j}+e_{i j},
\end{aligned}
$$

where $b_{0}$ captures network density, $N$ captures a set of variables that account for structural characteristics of the network (in and out degree, reciprocity, popularity difference, transitive and intransitive triads), $F$ contains two indicators of joint focal activity (same grade and the number of clubs to which both ego and alter both belong), and $B$ contains measures of the behavioral similarity of the dyad (difference in grade point average, SES differences, fighting, skipping school, and school attachment), and $e_{i j}$ is the dyadic error term. A clear advantage of this model is that $\exp \left(b_{1}\right)$ can be interpreted as the odds ratio for choosing a same-race friend. Since the scale of both $b_{1}$ and $\ln (\alpha)$ are the same, differences in the school-level model coefficients between the net and gross segregation result from the dyad-level factors accounted for in the net mode $1 .{ }^{13}$

\section{Independent Variables}

\section{Racial Distribution}

I measure the school's racial distribution with a generalized heterogeneity measure, calculated as

$$
\text { heterogeneity }=1-\sum_{k}\left(\frac{n_{k}}{N}\right)^{2}
$$

where $N=$ total school size and $n_{k}=$ number of people in group $k$. Heterogeneity can be interpreted as the probability that two randomly selected students will be of different races. ${ }^{14}$ Unlike the \%black or the

\footnotetext{
${ }^{13}$ Measurement details and model justification for the in-school model can be found in app. table A2.

${ }^{14}$ I code race and ethnicity into five categories: white, black, Hispanic, Asian, and mixed/other. Adolescents in Add Health were allowed to choose any number of race and ethnic identities. For my purposes, "white" refers to those who chose white as their only race $(52.5 \%)$, "black" as those who chose black $(15.6 \%)$ as their only race, "Hispanic" for those choosing any Hispanic ethnicity (17.4\%), "Asian" for those who chose Asian (4.7\%) as their only race/ethnic identity, and "other" contains those nonHispanic students who chose either a multiple race/ethnicity or "other" as their only race/ethnicity (9.9\%). If a given racial category made up less than $2 \%$ of the total school population, it was recoded as "other."
} 
\%nonwhite, the heterogeneity index has the advantage of working in all schools, regardless of the number of races or particular race combinations found in the setting. While past research has focused on a white/nonwhite distinction, many schools contain significant mixes of other race and ethnic groups. Limiting the discussion to only white and nonwhite students distorts the real distribution and general intergroup processes occurring in schools with significant divisions among nonwhite students.

\section{Focal Organization}

Using school administrator interviews, I measure three types of foci within schools: academic tracking, grade segregation, and extracurricular mixing. Each administrator was asked, "Approximately what percentage of your twelfth-grade students are in each of the following instructional programs (college preparatory, vocational/technical and general)?" For the purposes of this article, I have coded the percentage of students in vocational/ technical and general as "nonacademic" and measure the percentage of students in nonacademic tracks. ${ }^{15}$

I use Freeman's (1972) segregation index to measure both the extent to which friendships are bounded by grades and the extent to which extracurricular exposure is bounded by race. ${ }^{16}$ Grade in school is determined from student reports. I identify which people in a school are exposed to each other through extracurricular activities by constructing a joint activity network (Breiger 1974). The extracurricular activity network, $A$, is constructed by multiplying the set of activity indicators within each school by its transpose. That is, $A=P P^{\prime}$ where $P$ is an indicator matrix with a row for each person and a column for each extracurricular activity and $P_{i k}=1$ if actor $i$ is in activity $k$ and "0" otherwise. ${ }^{17}$ Elements of the resulting activity network, $A_{i j}$, equal the number of activities to which students $i$ and $j$ both belong. The segregation index is useful, because it adjusts cross-group contact for random expectation and can be used for both binary and valued data. This combination makes it applicable to the valued joint activity network as well as the binary same-grade net-

\footnotetext{
${ }^{15}$ Unfortunately, we do not know the distribution of race by track, or the distribution of tracks for the other grades.

${ }^{16}$ Freeman's segregation index is calculated as seg $=[E(X R)-X R] / E(X R)$, where $E(X R)$ is the expected number of cross-race contacts, and $X R$ is the observed number. The expectation is calculated as the product of the marginals of the category-bycategory mixing table, divided by the table total.

${ }^{17}$ The elements of $P$ are constructed from student reports of involvement in 31 activities covering sports, language, academics (debate, history, or science clubs), arts, and student life. Sports are separated by gender since males and females are usually members of separate teams.
} 


\section{American Journal of Sociology}

work. A value of "0" indicates a random mixing level, while a value of " 1 " means that relations are completely segregated. To substantively capture extracurricular exposure and bring its magnitude in line with the other coefficients, I reverse the extracurricular segregation index by multiplying it by -100 .

Two arguments suggest that it is reasonable to model friendship segregation as an outcome of extracurricular mixing instead of modeling extracurricular mixing as a function of friendship segregation. First, the primary mechanism by which racial friendship segregation could affect extracurricular mixing would be if friends joined activities together. By using net segregation $\left(b_{1}\right)$, we control for this dyadic activity overlap. Any observed effect of school-level extracurricular mixing is net of the exact membership overlaps of each dyad, indicating an effect at the level of school climate and generalized exposure (Stockard and Mayberry 1992). Second, we know from ethnographic reports (Quiroz et al. 1996) that administrators manipulate who participates in extracurricular activities, even if they currently do not do so with an eye toward racial integration. This implies that extracurricular mixing can be independently manipulated and could be used to bring races together in such activities. The endogeneity problem can never be ruled out entirely, particularly in the absence of longitudinal data on friendship segregation. Yet, the multilevel control implied by the use of $b_{1}$, combined with knowledge that administrators can control entry into extracurricular activity, provides support for modeling segregation as a function of extracurricular mixing. ${ }^{18}$

\section{Administrative Practice, Population Structure, and Control Variables}

To capture differences particular to school organization, I include an indicator for racial busing in the model, ${ }^{19}$ a measure of school SES, ${ }^{20}$ and

${ }^{18}$ An alternative strategy would be to use an instrumental variable. However, as is well known (Kennedy 1992), identifying good instruments that are not also reasonable controls to be included in the model, is extremely difficult. In this particular setting, any feature of the school that could serve as an instrument for extracurricular mixing is likely a strong independent candidate for inclusion in the model. Similar problems exist for a 2SLS model, since one needs to find factors that influence extracurricular mixing that do not plausibly also influence friendship segregation for the model to be identified. Substantively, any available measures that would increase race contact in extracurricular activities should also likely be included as a direct effect for friendship segregation.

${ }^{19}$ A school was coded as busing students if administrators said that "pupils are assigned from several geographic areas in order to achieve a desired racial or ethnic composition in the school." Administrators were not asked what proportion of their students were bused.

${ }^{20}$ Because the Add Health education and occupation categories are broadly defined, 
an indicator for public vs. private school. To account for Blau's (1977, 1994) work on population structure, I calculate the correspondence of race and SES using the multiple correlation coefficient of an in-school regression of SES on race. ${ }^{21}$ Both the faculty and student population likely determine the racial climate of a school. In schools where the faculty is heterogeneous, minority students may feel relatively less isolated and the overall racial climate may be more equitable, leading to greater friendship integration. School size provides a direct measure of mixing opportunity. Because students have more potential friends to choose from in large schools, tendencies for self-selection suggest that friendship segregation will increase with school size. ${ }^{22}$ In addition, large schools tend to be more heterogeneous than small schools, which could produce a spurious relation between heterogeneity and segregation. The history of racial and ethnic hostility in the South-especially surrounding school integration-suggests one should control for southern location (Orfield 1996; Orfield et al. 1997). Finally, characteristics of any network measure (such as friendship segregation) may depend on how well the network boundary is captured (Marsden 1990; Wasserman and Faust 1994). In schools where students nominated many out-of-school friends, the school and the substantive boundary of the network are not equivalent and the saliency of any characteristic within the school might be lowered.

\section{Model Specification}

I estimate each of the school-level models twice: once for the gross measure of segregation and once for the net measure. ${ }^{23}$ The general school-level model is

$$
\left[\ln (\alpha) \text { or } b_{1}\right]=d_{0}+d_{1-3} R+d_{4-7} F+d_{8-11} P+d_{12-18} C+e_{k},
$$

a simple family SES score was computed by summing five ranked categories of education (less than high school to advanced degree) and occupation (out of the labor force to professional) based on in-school student reports. While not ideal, this is the only measure of SES available for the in-school survey administration.

${ }^{21}$ The multiple regression of family SES on each race category measures the correlation across multiple diverse settings. The model used was SES $=a+X B+e$, where $B$ is a vector of $k-1$ race indicator variables for the $k$ races present in the school. In all regressions, "other race" was the omitted category.

${ }^{22}$ This effect is likely diminished with the net segregation models, since density is accounted for through the intercept of the in-school models.

${ }^{23}$ Most multilevel models simultaneously model the level-1 (individual) and level-2 (school) characteristics using a single maximum-likelihood estimation procedure. Unfortunately, the number of observations (many millions of dyads) makes this impossible with the current data. The efficacy of the two-equation approach is increased by the fact that, to the greatest extent possible, we have a complete census within each school, and thus the difference between the estimate of the in-school parameter, $b_{1}$, and the 


\section{American Journal of Sociology}

where $b_{1}$ is the coefficient for same-race dyads from the in-school dyad model and $\ln (\alpha)$ is the $\log$ of the odds ratio for a same-race friendship nomination. These dependent variables are modeled as a function of four domains: a school's race and ethnic distribution $(R)$, differences in focal organization ( $F$ : tracking, grade-segregation, and extracurricular exposure), differences in the school population ( $P$ : school busing, school type, mean SES, and SES consolidation), and a vector of school and community control variables $(C$ : faculty heterogeneity, network boundary, density, region, urban, rural, and size).

\section{RESULTS}

Friendship Segregation Levels

Friendships in the Add Health sample are highly segregated by race. In general, the average value of alpha over the entire sample is 1.84 , indicating that the average odds of nominating a same-race friend are about 1.8 times the odds of nominating a cross-race friend. The level of observed segregation varies dramatically by school and is somewhat skewed. While many schools have nearly perfect integration $(\alpha \approx 1)$, in about $8 \%$ of the sample, alpha is greater than five. The gross measure of segregation reflects the segregation one would observe in a school based solely on the distribution of relationships by race. It is what administrators, parents, and other students in a school experience. Net friendship segregation is considerably lower than gross friendship segregation, with an average odds ratio of $1.26 .{ }^{24}$ Controlling for dyadic factors, the odds of a samerace friendship tie are about 1.26 times higher than the odds of a crossrace friendship tie. This difference in levels indicates that much of the observed friendship segregation in schools is due to factors such as belonging to the same clubs, having similar behaviors, and maintaining social balance. As such, the revealed preference for same-race friendship is significantly lower than that which would be inferred from the observed volume of cross-race freiendship ties.

Heterogeneity and Racial Relating

How are racial heterogeneity and friendship segregation related? Figure 3 plots the net friendship segregation $\left(b_{1}\right)$ of each school by its

true parameter, $\beta_{1}$, is likely small. A two-equation approach is not without precedent, and while somewhat cumbersome, has been used effectively in the past (for discussion, see Aspin 1988; DiPrete and Forristal 1994; Iversen 1991).

${ }^{24}$ Gross and net values are significantly different at the 0.0001 level, as judged by a survey-corrected adjusted Wald test. 
Friendship Segregation

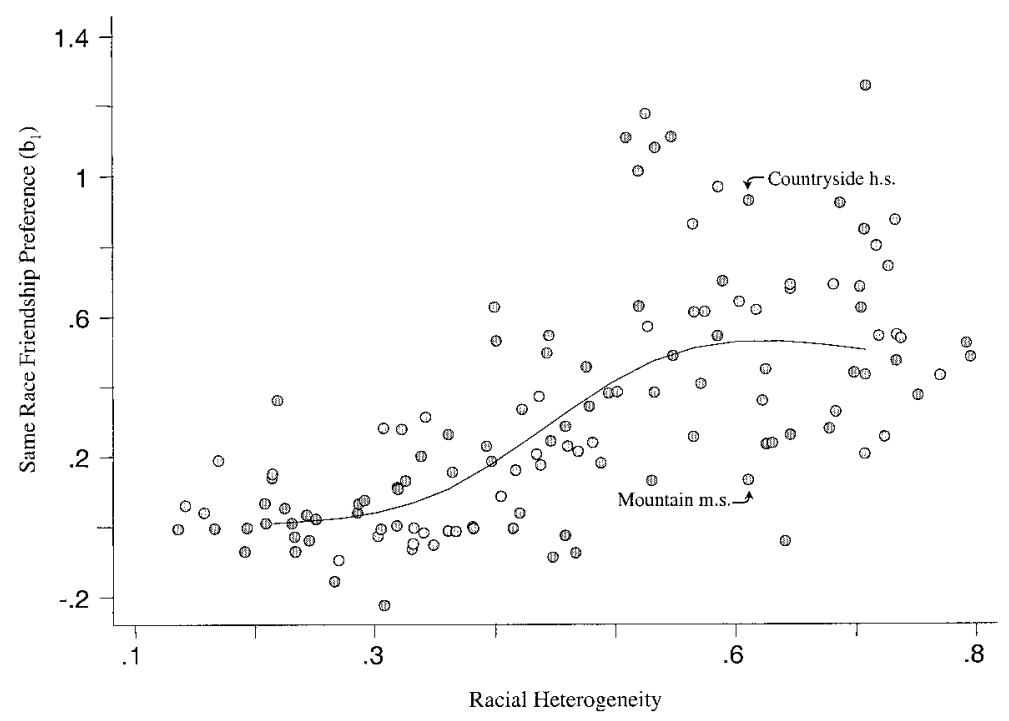

FIG. 3.-Friendship segregation and racial heterogeneity

racial heterogeneity. For reference purposes, the two schools from figures 1 and 2 are marked on the scatter plot. ${ }^{25}$ In general, there is a strong positive correlation between a school's racial heterogeneity and friendship segregation. The relationship is curved because in schools with low heterogeneity race is simply not salient, while the salience of race appears to level off (and even drop slightly) at the highest levels of racial heterogeneity. ${ }^{26}$

This relationship is not uniform, since some racially heterogeneous schools (like Countryside High School) have high friendship segregation, while other heterogeneous schools (such as Mountain Middle School) have low friendship segregation. This suggests that while friendship segregation tends to increase with racial heterogeneity, it need not, as some settings exhibit near perfect friendship integration $\left(\ln (\alpha) \approx b_{1} \approx 0\right)$, even at high levels of racial heterogeneity.

\section{Multivariate Models}

Table 3 presents the school-level regression results for racial friendship segregation.

${ }^{25}$ The figure is not substantively different if $\alpha$ is used instead of $b_{1}$, except that the overall level of segregation is higher.

${ }^{26}$ The curve fit in fig. 3 is based on a smoothed three-knot cubic spline, as implemented in STATA 6.0. The plot is not weighted, but the observed correlation is. 
TABLE 3

Survey Design Corrected Regression of Friendship Segregation on School Characteristics

\begin{tabular}{|c|c|c|c|c|c|c|c|c|}
\hline \multirow[b]{2}{*}{ VARIABLE } & \multicolumn{2}{|c|}{ Model 1} & \multicolumn{2}{|c|}{ Model 2} & \multicolumn{2}{|c|}{ MODEL 3} & \multicolumn{2}{|c|}{ Model 4} \\
\hline & $b_{1}$ & $\alpha$ & $b_{1}$ & $\alpha$ & $b_{1}$ & $\alpha$ & $b_{1}$ & $\alpha$ \\
\hline Intercept & $\begin{array}{l}.96^{* * *} \\
(.28)\end{array}$ & $\begin{array}{l}1.61 * * * \\
(.41)\end{array}$ & $\begin{array}{l}1.15 * * * \\
(.27)\end{array}$ & $\begin{array}{l}1.73 * * * \\
(.27)\end{array}$ & $\begin{array}{l}.86 * * \\
(.32)\end{array}$ & $\begin{array}{l}1.64 * * * \\
. .36)\end{array}$ & $\begin{array}{l}.62 \\
(.34)\end{array}$ & $\begin{array}{l}1.05^{*} \\
(.41)\end{array}$ \\
\hline Race distribution: & & & & & & & & \\
\hline Heterogeneity & $\begin{array}{c}-9.26^{* * * *} \\
(2.3)\end{array}$ & $\begin{array}{c}-13.50 * * * \\
(3.18)\end{array}$ & $\begin{array}{c}-7.59 * * * \\
(1.99)\end{array}$ & $\begin{array}{c}-11.11 * * * \\
(2.21)\end{array}$ & $\begin{array}{c}-6.81^{* *} \\
(2.17)\end{array}$ & $\begin{array}{c}-9.93 * * * \\
(2.20)\end{array}$ & $\begin{array}{c}-5.32 * * \\
(1.88)\end{array}$ & $\begin{array}{c}-7.99 * * * \\
(2.13)\end{array}$ \\
\hline Heterogeneity $^{2}$ & $\begin{array}{l}26.42 * * * \\
(5.8)\end{array}$ & $\begin{array}{l}38.11 * * * \\
(8.36)\end{array}$ & $\begin{array}{l}21.16^{* * *} \\
(4.72)\end{array}$ & $\begin{array}{l}29.93 * * * \\
(5.57)\end{array}$ & $\begin{array}{l}19.17 * * * \\
(5.22)\end{array}$ & $\begin{array}{l}26.61 * * * \\
(5.69)\end{array}$ & $\begin{array}{l}15.55 * * \\
(4.58)\end{array}$ & $\begin{array}{l}22.03 * * * \\
(5.57)\end{array}$ \\
\hline Heterogeneity $^{3}$. & $\begin{array}{c}-20.13 * * * \\
(4.51)\end{array}$ & $\begin{array}{l}-28.80 * * * \\
(-6.51)\end{array}$ & $\begin{array}{c}-16.02 * * * \\
(3.47)\end{array}$ & $\begin{array}{c}-22.11 * * * \\
(4.22)\end{array}$ & $\begin{array}{c}-14.57 * * * \\
(3.76)\end{array}$ & $\begin{array}{c}-19.57 * * * \\
(4.34)\end{array}$ & $\begin{array}{c}-11.72 * * * \\
(3.30)\end{array}$ & $\begin{array}{c}-15.96 * * * \\
(4.23)\end{array}$ \\
\hline Focal organization: & & & & & & & & \\
\hline Tracking $. . . \ldots .$. & & & $\begin{array}{c}-.05 \\
(.18)\end{array}$ & $\begin{array}{l}.43 \\
(.27)\end{array}$ & $\begin{array}{c}-.19 \\
(.18)\end{array}$ & $\begin{array}{l}.36 \\
(.30)\end{array}$ & $\begin{array}{c}-.04 \\
(.22)\end{array}$ & $\begin{array}{l}.67^{*} \\
(.31)\end{array}$ \\
\hline Tracking $^{2}$ & & & $\begin{array}{l}.06 \\
(.18)\end{array}$ & $\begin{array}{c}-.41 \\
(.24)\end{array}$ & $\begin{array}{l}.15 \\
(.17)\end{array}$ & $\begin{array}{l}-.41 \\
(.27)\end{array}$ & $\begin{array}{c}-.01 \\
(.20)\end{array}$ & $\begin{array}{c}-.75 * * \\
(.26)\end{array}$ \\
\hline Grade segregation $\ldots . .$. & & & $\begin{array}{c}-.47 * * \\
(.19)\end{array}$ & $\begin{array}{c}-.47 * \\
(.23)\end{array}$ & $\begin{array}{c}-.49^{* *} \\
(.17)\end{array}$ & $\begin{array}{l}-.28 \\
(.27)\end{array}$ & $\begin{array}{c}-.45 * * \\
(.17)\end{array}$ & $\begin{array}{c}-.21 \\
(.24)\end{array}$ \\
\hline Extracurricular mixing ... & & & $\begin{array}{c}-.07 * * * \\
(.008)\end{array}$ & $\begin{array}{c}-.10 * * * \\
(.01)\end{array}$ & $\begin{array}{c}-.07 * * * \\
(.009)\end{array}$ & $\begin{array}{l}-.10^{* * * *} \\
(.02)\end{array}$ & $\begin{array}{c}-.05 * * * \\
(.01)\end{array}$ & $\begin{array}{c}-.08 * * * \\
(.02)\end{array}$ \\
\hline
\end{tabular}




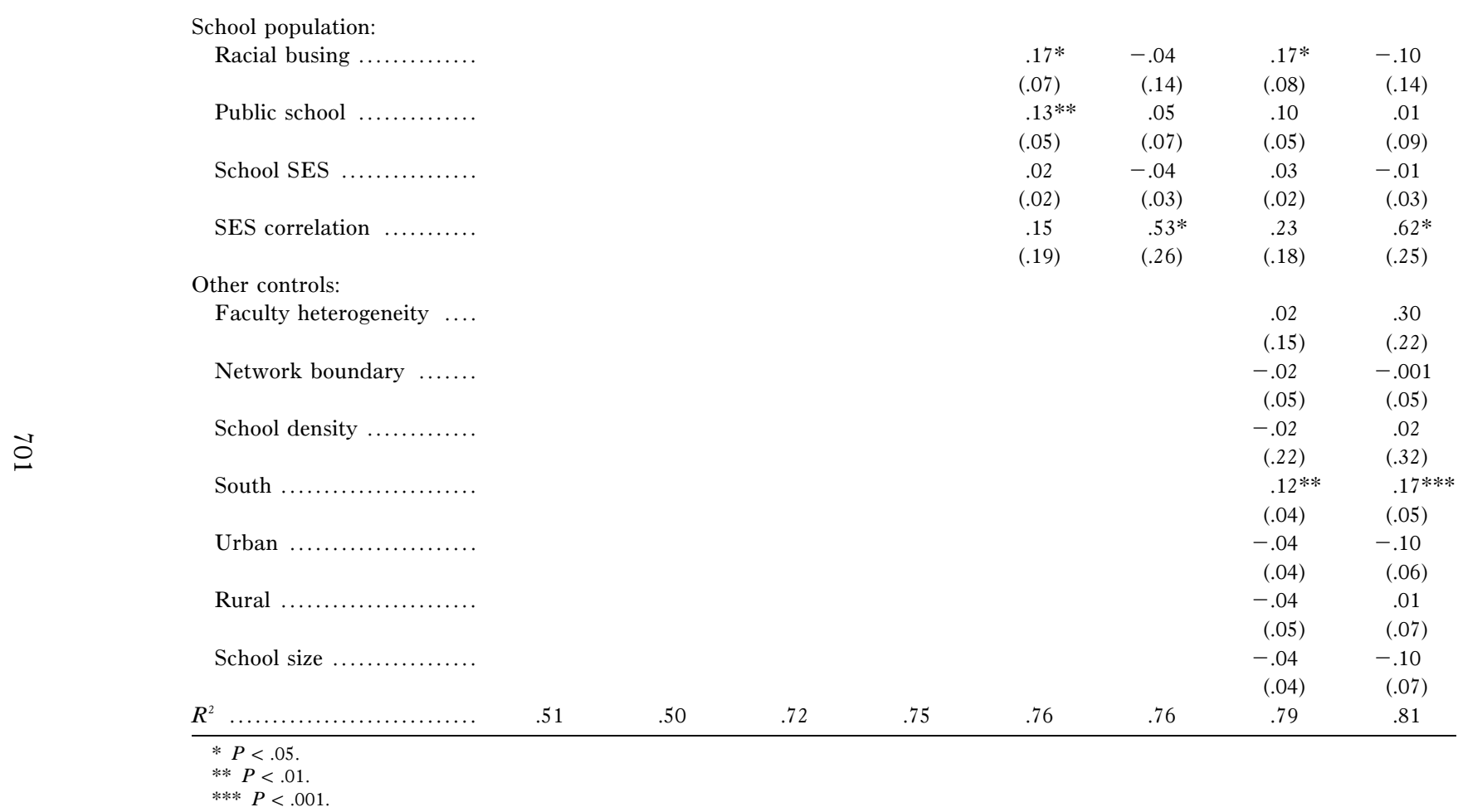




\section{American Journal of Sociology}

\section{Race Distribution}

The first model in table 3 describes the relation between racial heterogeneity and friendship segregation. ${ }^{27}$ The curve evident in figure 3 suggests that the relation between heterogeneity and friendship segregation is not linear, and tests for a third-order polynomial indicate that a curved specification best fits the data. ${ }^{28}$ The curve described in model 1 mimics the curve shown in figure 3 , with a sharp peak in segregation at the middle range of heterogeneity, decreasing slightly at the upper end of the distribution (see fig. 4). while intriguing, we cannot be certain of the magnitude of this effect unless it holds net of other factors that might account for differences in heterogeneity and friendship segregation. The remaining models in table 3 test the multivariate specifications, with models 2 and 3 differing from 4 only in the set of controls included in the specification.

In model 4 , the most completely specified model, the three-term heterogeneity specification is included along with the focal organization, school population, and control variables. The heterogeneity terms are statistically significant for both measures of friendship segregation, indicating that the relation between heterogeneity and friendship segregation is not a spurious result of other school factors. Since the three-term equation for heterogeneity is difficult to interpret, figure 4 presents the expected same-race friendship odds ratio $\left(\exp \left(b_{1}\right)\right)$ by the school's racial heterogeneity, for an otherwise average school based on model $4 .{ }^{29}$

At low levels of racial heterogeneity, the relative odds ratio for a samerace friendship within the school $\left(\exp \left(b_{1}\right)\right)$ approaches 1 . As racial heterogeneity increases, race becomes more salient for friendship and the tendency for same-race friendship increases significantly, only to decrease again at the highest levels of racial heterogeneity. ${ }^{30}$ In general, it appears

\footnotetext{
${ }^{27}$ Because of the clustered and stratified design of the Add Health survey, standard errors estimated without corrections will likely be too small and significance tests incorrect. To correct for sample clustering and unequal sampling probability, I employ sampling weights and use the survey estimation routines available in STATA 6.0. Additionally, one small, private southern school did not provide information on tracking, and is thus not used in the model. Because regression coefficients can be sensitive to model specification, I specify multiple versions of the model.

${ }^{28} \mathrm{~A}$ simple model without the third-order polynomial results in a 0.95 coefficient for net segregation and 1.38 for gross friendship segregation, both significant at the 0.0001 level.

${ }^{29}$ I calculated predicted values by estimating $b_{1}$ from model 4 , substituting mean values for all continuous variables (except heterogeneity) and mode values for dummy variables and varying racial heterogeneity.

${ }^{30}$ The equation reaches a local maximum at racial heterogeneity $\approx 0.65$, with an expected OR of 1.62, dropping to 1.33 at a heterogeneity level of 0.8 . The magnitude of the drop in segregation at the high end is somewhat difficult to judge. The bivariate plot in fig. 3 indicates that the degree of segregation levels off at high levels of seg-
} 


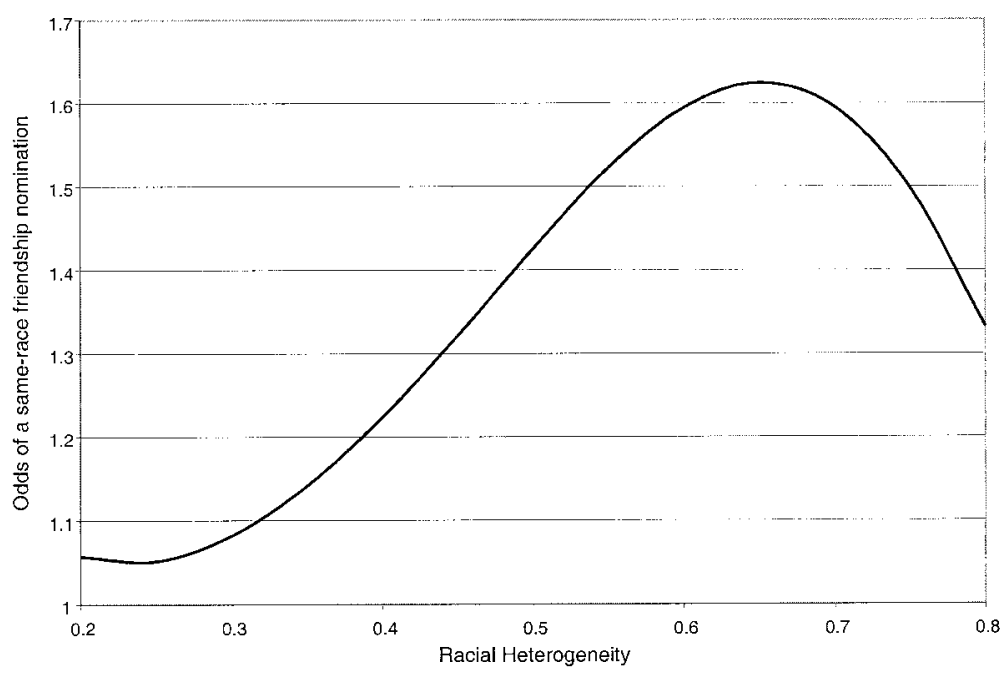

FIG. 4.- Relation between net odds ratio for a same-race friendship $\left(\exp \left(b_{1}\right)\right)$ and racial heterogeneity in schools.

that as racial heterogeneity increases in schools, the observed preference for same-race friendship choices also increases, though not at a constant rate. The sharp increase in friendship segregation at heterogeneity roughly equal to 0.3 is reminiscent of tipping point arguments suggesting that race becomes salient only after a critical mass is reached (See Giles 1978; Blalock 1967). The curve evident from model 4 suggests that while the odds ratio for same-race friendship choice increases most dramatically between 0.3 and 0.65 , it declines as racial heterogeneity becomes more pronounced. This moderate level of heterogeneity is common in relatively balanced two-race schools.

While schools are legally mandated to integrate, this finding suggests that increasing racial diversity within the school might heighten relational segregation. While this result might seem inconvenient for supporters of school integration, three factors mitigate this negative interpretation. First, it is important to realize that while the odds-ratio for same-race friendship ties might increase, for the reasons expressed by Feld and Carter (1998), the number of cross-race ties might also increase. As heterogeneity increases in a school, opportunities for making cross-race ties increase, but the observed rate at which cross-race ties are made does not keep up with that opportunity. Second, as I discuss in detail below, features of the

regation but does not decrease much. A spline (knotted at 0.3 and 0.65 ) also indicates a decline in segregation at the highest levels of racial heterogeneity, suggesting that the decline in segregation is real. 


\section{American Journal of Sociology}

school organization can be identified that independently lower the level of racial friendship segregation. These features can help to mitigate the self-selection pressures evident in the presence of racial heterogeneity. Third, the right-hand side of the curve in figure 4 suggests that schools face a two-stage battle. Schools with intermediate levels of racial heterogeneity-roughly between 0.3 and 0.65 -will see the largest increases in friendship segregation. However, once the peak has been passed, highly heterogeneous schools may have a better time of it.

\section{Focal Organization}

Turning to factors that schools can control, the three focal organization characteristics (proportion in nonacademic tracks, grade segregation, and extracurricular mixing), each show some relation to segregation. Since the proportion of students in nonacademic tracks is expected to have an inverted $U$-shape relation with friendship segregation, I enter proportion in nonacademic tracks along with its square. ${ }^{31}$ While the coefficients for net segregation $\left(b_{1}\right)$ are not statistically different from zero, those for gross segregation $(\alpha)$ are. For gross friendship segregation, the models suggest that friendship segregation reaches a peak at about 0.45 , with an expected odds ratio of 2.08. That the squared term is larger in magnitude (and the peak is less than 0.5 ) indicates that the overall relation is slightly negative, as predicted by the model. One interpretation of the difference between models is that factors selecting students into similar tracks-and thus leading to friendship within tracks-are accounted for in the dyad-level models. ${ }^{32}$

While it is impossible to determine from these models how tracking practices shape friendship selection beyond simple exposure, any difference between these two models could follow from student self-selection or changes in preferences induced by track membership. If students with particular interests self-select into tracks, then the factors that lead to track selection are probably the same homophily characteristics netted from $b_{1}$ by the dyad model. On the other hand, if track assignment in-

\footnotetext{
${ }^{31}$ Models without the square term show no relation between track assignment and friendship segregation.

${ }^{32}$ Testing coefficient values across different dependent variables is never straightforward. Because the models are based on the same sample, independent sample tests (Cohen and Cohen 1983, p. 111) are not appropriate. Instead, we can test for the equality of the two coefficients by stacking the data used for the two models (moving from $N$ to $2 N$ cases) and introducing interaction terms to separate the models. If the interaction term for a particular variable is significant, then the coefficients for the two models differ. Using this approach, the tracking coefficients are statistically different across the two dependent variables.
} 
fluences behavior-by direct instruction or exposure to different options-then the model differences result from school practice, which may point to a particular policy lever for schools because increasing the exposure of whites to blacks within tracks may increase cross-race contact. Unfortunately, nothing in the cross-sectional models presented here can disentangle the potential causal ordering of these events.

The extent to which friendships are focused in grades has a marked effect on net segregation, while not being significantly different for gross segregation. ${ }^{33}$ That is, net of dyad-level factors and other school-level factors, when friendships fall within grades, racial segregation decreases. Grade segregation is an element that schools have some control over. It is likely that most mixing between grades occurs in elective courses and free periods. By scheduling free periods and elective courses to be singlegrade, people will be limited in their cross-grade contacts and will be more likely to choose cross-race friends. Unlike race or track, a constraint on grade-mixing is substantively innocuous since it is universal (there is no judgement about superiority, as often implied by track assignments, and every student of the same general age is in the same grade) and irrelevant after graduation. Schools with high levels of heterogeneity might mitigate the self-segregation effect by emphasizing within-grade interaction.

The third feature of school organization that administrators can control-the extent of extracurricular mixing — exhibits a consistent relation to both gross and net friendship segregation. Friendship segregation is lower in schools with integrated extracurricular programs. The effect is strong. A one standard deviation increase in extracurricular exposure decreases racial segregation by about one third of a standard deviation. ${ }^{34}$ That this is so for net segregation-where joint membership in extracurricular activities is captured directly at the dyad level-indicates a true contextual effect. At the dyad level, the more activities that ego and alter share, the greater the likelihood that they will be friends. ${ }^{35}$ However, even controlling for the direct effect of joint activity in settings where the extracurriculum is integrated, friendship relations tend to be integrated. This suggests that such settings produce a school climate that is conducive to interracial friendship. Since administrators have a great deal of control over who participates in the extracurricular activities (Quiroz et al. 1996),

\footnotetext{
${ }^{33}$ The coefficients are not statistically different across models.

${ }^{34}$ Standardized coefficients are not directly available for the survey regression estimates. If you estimate the model using WLS instead, extracurricular exposure has the largest standardized coefficient after heterogeneity.

${ }^{35}$ Based on the in-school models, the average odds of friendship increase by 1.26 for each additional activity of which both ego and alter are members.
} 


\section{American Journal of Sociology}

this suggests a policy tool that school administrators can use to help build relational integration. That each focal factor holds net of other controls in the model that might generate a spurious result between extracurricular, grade, or tracking practices and friendship segregation, supports the idea that these factors may be useful policy levers for schools trying to integrate substantively. ${ }^{36}$

The effect of these three organizational factors on racial friendship segregation suggests that Feld and Carter's (1998) proposed concentration of minority students in large schools must be tempered with respect to how schools are organized internally. The Add Health data suggest that while such concentration may increase the possibility for cross-group contact, revealed same-race friendship preference increases unless organizational steps are taken to mitigate self-selection into same-race friendship groups. Without organizational structures to ensure status equality within the school, minority concentration may lead to greater friendship segregation, even as the absolute number of cross-race ties increases.

\section{School Administration, Population Structure, and Control Variables}

School busing is not statistically significant for gross segregation, but it is significant for net segregation. ${ }^{37}$ In schools that have a busing program, the net odds ratio of a same-race friendship choice are 1.18 times the odds ratio of a same-race friendship choice in a similar nonbusing school. This indicates that nongeographic-based racial heterogeneity might exacerbate racial friendship segregation, which likely reflects the hostilities generated by school busing. Of the other three variables that capture features of the school population-public vs. private school, mean SES, and the consolidation of SES and race-only Blau's social consolidation is significantly different from zero, and only for the gross segregation index. ${ }^{38} \mathrm{In}$ schools where SES and race are highly correlated, the level of observed friendship segregation will be higher, as predicted by Blau.

The only other control variable that shows a significant relation with

${ }^{36}$ Not all extracurricular activities are the same, as some sports-such as basketball-require strong team efforts, while other sports—such as track-are more individualistic. As such, we might expect that the power of mixing differs by the type of groups in which students mix. We can examine this by separating exposure within team sports. When I do so, I find a strong effect for team sports, but an overall model fit that is lower than that which is found using all activities. This is true even if exposure through other activities are entered separately. This implies that mixing through multiple extracurricular contexts adds additional power to the model.

${ }^{37}$ The coefficients for net and gross segregation are not statistically different from each other.

${ }^{38}$ The coefficients for net and gross segregation are statistically different from each other. 
relational segregation is the indicator for a southern school. Both gross and net relational segregation are higher, net of all other school features, in southern schools. This likely indicates that the cultural and political heritage of race in southern schools is still reflected in the patterns of friendship relations. Work on racial distributions within schools has shown that the northeast is becoming segregated faster than any other part of the country (Orfield 1996; Orfield et al. 1997). The findings in this article suggest that while schools in the northeast may be more racially isolated, schools in the south tend to exhibit the greatest level of friendship segregation, net of school heterogeneity. This finding reinforces the idea that the simple degree of racial mixing is not sufficient to understand substantive student racial interaction. As such, schools in the south start from a higher base of segregation that will be that much more difficult to overcome.

\section{CONCLUSION}

This article examined the relation between racial heterogeneity and friendship segregation and identified school features that affect friendship segregation. Part of the motivation behind the Brown decision was the recognition that informal social relations are an important part of the educational experience. Unfortunately, most previous work on integration has focused on the distribution of race within schools, implicitly assuming that racial heterogeneity would promote relational integration. Contact theory, however, suggests that the likelihood of cross-race friendship given exposure depends on the status structure and activities within settings. If contact theory is correct, then increasing heterogeneity need not increase racial friendship integration. The evidence from this study supports contact theory on two dimensions. First, I find a strong and generally positive relation between heterogeneity and friendship segregation, though the relation is not linear. This finding suggests that simple exposure does not promote integration. Second, I find that interracial mixing within settings that capture the positive elements of contact theory (status equality and interdependent action) promotes friendship integration.

The problem of racial friendship segregation is inherently multilevel: individuals choose friends but do so within the opportunities and constraints provided by the school context. This article focused on the interaction between school context and same-race friendship preference, since administrators have some control over organizational features that might be used to promote interracial friendship. The dyad-level model used in this article identified homophily and balance as important aspects of friendship choice. In general, friends tend to be similar across multiple 


\section{American Journal of Sociology}

dimensions and relations tend to be balanced. Future work needs to identify the contextual effects for behavioral homophily and social balance. For example, balance theory rests on the strain produced when friends of friends are not friends with each other. However, if imbalanced friendships are distributed across multiple settings, strain may not result and balance will be less significant. If race is similarly distributed across settings, then balance will be less important for interracial friendship. That net friendship segregation is significantly lower than gross friendship segregation indicates that individual and network factors have a marked effect on racial mixing. Future work on racial mixing needs to identify the particular mechanisms (such as the interaction between balance and race) that account for this difference.

At the school level, as racial heterogeneity increases, people's samerace preference also increases, but not linearly. While self-segregation is expected given a known preference for similarity in friendship, what accounts for the curvilinear relation between heterogeneity and friendship segregation? I suspect that the curvilinear relation results from the interplay of relative group size and the number of races in the school. As minority size increases, the social salience of race also increases. Two linked processes likely occur once race becomes salient within a school. On the one hand, majority members may start to see minorities as a potential status threat once their numbers increase significantly. On the other hand, increasing numbers allow minorities to identify same-race friends that match on other attributes, leading to an increase in samerace friendship choice within the minority group. Once started, this process likely snowballs as increased same-race preference within one race solidifies the group structure within that race, making them appear more unified (and thus a greater status threat) to the other group.

Why then would segregation decrease in the most diverse settings? Here, I suspect the answer has to do with the number of races in any setting. Heterogeneity reaches a maximum of 0.5 when there are only two races in the school, and thus the decreasing levels of segregation only occur in schools with more than two races. When there are only two races in the school, there is a greater likelihood for "us vs. them" social dynamics. Once we move beyond two groups, however, multiple dynamics may mitigate racial segregation. First, differences in race-specific mixing patterns may create bridges between groups that help unite the entire school. Whites, on average, are more likely to nominate Hispanics than to nominate blacks, but Hispanics are more likely to nominate blacks than to nominate whites. As such, Hispanics may serve to bridge whites and blacks within a school. ${ }^{39}$ Second, when heterogeneity is highest, every

\footnotetext{
${ }^{39}$ Race-specific mixing tables are available from the author on request.
} 
group is a small minority relative to the rest of the school (in this sample, when heterogeneity is at a maximun, each race can make up only $20 \%$ of the total population). Substantively, such a setting is very similar to low heterogeneity schools, where no single race dominates the social scene. The combination of low overall presence and differential mixing patterns results in decreased racial segregation at the highest levels of heterogeneity.

Future work needs to identify the source of race-specific mixing preferences. One way that we could identify the group dynamics suggested by the hetrogeneity-segregation relation would be to differentiate samerace preference by minority and majority status. If majority members are reacting to a perceived status threat posed by minority presence before minorities form a cohesive group, then I would expect to find the majority same-race preference increase faster than minority same-race preference. If, however, minorities come together first, then I would expect to find increased minority same-race preference at lower levels of racial heterogeneity. Thus, the difference between when friendship segregation peaks for minority and majority members could identify whether majority members are rejecting minorities or vice versa.

The second major finding of this article is that school organization affects racial friendship segregation by structuring interracial contact. The strongest effect of school organization on racial friendship is through extracurricular mixing. Schools that succeed in mixing students by race in extracurricular activities have lower levels of racial friendship segregation. This finding holds controlling for dyadic exposure through joint activity membership (which has a strong independent influence on friendship), suggesting that a more generalized school climate effect is operating. Schools where extracurricular activities are integrated likely provide an environment that supports interracial friendship. Future work on this finding needs to identify how extracurricular activities shape school climate. Does this result follow from administrative behavior within extracurricular activities (e.g., supportive coaches) or by increasing overall school morale?

Focal organization effects were also evident through within-grade mixing and the structure of tracking in schools. In both cases, when the focal organization cross-cuts race, interracial contact increased. The gradesegregation effect is most clear in this respect and might suggest a limiting interaction between contact theory and mixing opportunity. Contact elements likely matter most when there are sufficient options for friendship choice, but they decrease in importance when a setting sufficiently constrains people's friendship opportunities. As such, schools could increase interracial contact by limiting cross-grade contact. Tracking, on the other hand, combines both exposure and contact features. When schools disproportionately assign minority students to nonacademic tracks, they add 
American Journal of Sociology

an additional status distinction between races, lowering contact opportunity and decreasing cross-race friendship.

Allport's (1954) contact theory strikes at the heart of the multilevel problem of race segregation in schools. School organizational features affect students' relational preferences. When students of different races have the opportunity to work together for collective ends in settings of relative equality, substantive integration results. At least three significant extensions are required before strong causal or policy conclusions can be drawn. First, the patterning of friendship choice needs to be explored longitudinally. Only by examining friendship choice and change-conditional on an actor's past pattern of relations, behavior trajectory, and organizational involvement - can we disentangle the mechanisms that drive global relational patterns. Previous work suggests that interracial friendships tend to be less stable than same-race friendships (Hallinan and Williams 1987), but we have not identified how school organization might affect relational stability. Second, schools are situated within communities, and the patterns of racial segregation are likely reflected within the school. Extensions of this work need to explore how geographic and economic segregation in the community relate to the pattern of relations within the school. Finally, a school's primary purpose is to educate and prepare adolescents for adulthood. Future research needs to identify how interracial friendship patterns affect student performance and, in turn, how such relations prepare students for a racially diverse work environment. Future waves of data from the National Longitudinal Study of Adolescent Health will provide a unique opportunity to answer these questions.

\section{APPENDIX}

Specifying the In-school Network Models

The in-school model I estimate incorporates factors from three domains: structural features of the network, exposure factors that likely bring actors together within foci, and homophily behaviors. I use a comprehensive specification of the in-school model, since the more completely this model is specified, the greater faith we can have that the resulting measure of friendship segregation captures same-race friendship preference.

The first factor that affects friendship probability is the number of nominations each student sends (out-degree) or receives (in-degree). (For every dyad, alter in-degree is calculated as the number of people other than ego who nominates alter.) Friendships tend to be reciprocated, and thus the probability that $i$ nominates $j$ should increase if $j$ nominates $i$. Reciprocity is coded " 1 " every time alter nominates ego. Since social status 
in school is reflected through popularity, and popular students tend to nominate each other as friends, I include the popularity difference between each member of the dyad. Finally, since friendship networks tend toward balance, two parameters that capture the change in the number of transitive and intransitive triples are included. Next, two salient foci within schools are grade and involvement in common extracurricular activities. (Additionally, it would be useful to know which track a given student belonged to. Unfortunately, no information about which school track a student belongs to is available.) If two students share many activities and spend more time in each other's company, they are more likely to be friends than are those who have no activities in common. Each pair is coded for being in the same grade and for the number of extracurricular activities that they have in common. Finally, while homophily operates along multiple dimensions, I focus on characteristics that might be related to race, such as family SES, school performance, school attachment, and minor delinquency (fighting and skipping school). To account for differences by gender, I also include a parameter for same gender (Dunphy 1963; Cotterell 1996). Finally, the extent of racial friendship segregation is captured by the parameter for same-race, coded " 1 " if both students are of the same race and "0" otherwise. The coefficient for this parameter describes the revealed net preference for same-race friendships within the school.

TABLE A1

Comparison of Schools in the Network Sample to Nonnetwork Sample

\begin{tabular}{|c|c|c|}
\hline School Attribute & $\begin{array}{l}\text { Network } \\
\text { Sample }\end{array}$ & $\begin{array}{c}\text { Nonnetwork } \\
\text { Sample }\end{array}$ \\
\hline Size (small, medium, large) $(\%)$ & $57,33,9$ & $74,10,16$ \\
\hline Racial heterogeneity* & .51 & .39 \\
\hline Urban, suburban, rural $(\%) \ldots \ldots \ldots \ldots \ldots \ldots \ldots \ldots$ & $21,59,20$ & $27,65,8$ \\
\hline Region (West, Midwest, South, Northeast) (\%)*** ... & $10,41,33,15$ & $61,11,21,7$ \\
\hline Mean SES & 5.9 & 6.1 \\
\hline \multicolumn{3}{|l|}{ School type: } \\
\hline Public nonspecialized (\%) & 70 & 57 \\
\hline Public specialized $(\%) \ldots \ldots$. & 15 & 13 \\
\hline Private religious $(\%) \quad \ldots \ldots \ldots \ldots \ldots \ldots \ldots \ldots \ldots$ & 14 & 30 \\
\hline Private nonreligious $(\%) \ldots$. & 1 & 0 \\
\hline Tracking $(\%)^{*} \ldots \ldots \ldots \ldots \ldots \ldots \ldots \ldots \ldots$ & 45 & 13 \\
\hline Junior high school $(\%) \ldots$ & 53 & 42 \\
\hline Students testing at or above grade (\%) & 83 & 85 \\
\hline 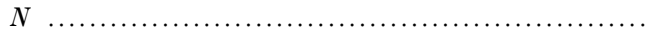 & 112 & 18 \\
\hline
\end{tabular}


TABLE A2

In-School Equation Variables and Descriptive Statistics

\begin{tabular}{|c|c|c|c|}
\hline Variable & Description & Mean & $\mathrm{SD}$ \\
\hline Friendship nomination & $\begin{array}{l}\text { Coded " } 1 \text { " if ego nominates } \\
\text { alter }\end{array}$ & .006 & .08 \\
\hline Ego out-degree .... & $\begin{array}{l}\text { Number of people, other than } \\
\text { alter, that ego nominated as } \\
\text { a friend }\end{array}$ & 4.06 & 2.99 \\
\hline Alter in-degree $\ldots \ldots \ldots \ldots$ & $\begin{array}{l}\text { Number of people, other than } \\
\text { ego, who nominated alter }\end{array}$ & 4.06 & 3.49 \\
\hline Reciprocity & $\begin{array}{l}\text { An indicator if alter nomi- } \\
\text { nated ego }\end{array}$ & .006 & .08 \\
\hline Transitivity $\ldots \ldots \ldots \ldots \ldots$ & $\begin{array}{l}\text { Change in the number of } \\
\text { transitive triples observed } \\
\text { in the network if ego were } \\
\text { to nominate alter }\end{array}$ & .10 & .57 \\
\hline Intransitivity $\ldots \ldots \ldots \ldots$ & $\begin{array}{l}\text { Change in the number of in- } \\
\text { transitive triples observed } \\
\text { in the network if ego were } \\
\text { to nominate alter }\end{array}$ & 8.03 & 4.77 \\
\hline Popularity difference $\ldots .$. & $\begin{array}{l}\text { Absolute value of the differ- } \\
\text { ence in number of nomina- } \\
\text { tions ego and alter receive }\end{array}$ & 3.48 & 3.23 \\
\hline Same race $\ldots \ldots \ldots \ldots \ldots$ & $\begin{array}{l}\text { Coded " } 1 \text { " if ego and alter are } \\
\text { the same race }\end{array}$ & .51 & .49 \\
\hline Same sex $\ldots$ & $\begin{array}{l}\text { Coded "1" if ego and alter are } \\
\text { the same gender }\end{array}$ & .52 & .50 \\
\hline Same grade ........ & $\begin{array}{l}\text { Coded " } 1 \text { " if ego and alter are } \\
\text { in the same grade }\end{array}$ & .30 & .46 \\
\hline Overlapping clubs $\ldots \ldots \ldots$ & $\begin{array}{l}\text { Number of extracurricular } \\
\text { activities that both ego and } \\
\text { alter are members of }\end{array}$ & .23 & .56 \\
\hline GPA difference... . & $\begin{array}{l}\text { Absolute value of the differ- } \\
\text { ence in ego and alter's } \\
\text { grade point average }\end{array}$ & .80 & .61 \\
\hline SES difference $\ldots$ & $\begin{array}{l}\text { Absolute value of the differ- } \\
\text { ence in ego and alter's SES }\end{array}$ & 2.54 & 1.96 \\
\hline Fight $\ldots \ldots \ldots \ldots \ldots$ & $\begin{array}{l}\text { Coded " } 1 \text { " if ego and alter } \\
\text { both reported being in a } \\
\text { physical flight in the last } \\
\text { year }\end{array}$ & .23 & .42 \\
\hline Skipping school .... & $\begin{array}{l}\text { Coded "1" if ego and alter } \\
\text { both reported having } \\
\text { skipped school in the previ- } \\
\text { ous year }\end{array}$ & .11 & .32 \\
\hline
\end{tabular}


Friendship Segregation

TABLE A2 (Continued)

\begin{tabular}{|c|c|c|c|}
\hline Variable & Description & Mean & SD \\
\hline Attachment & $\begin{array}{l}\text { Absolute value of the differ- } \\
\text { ence in school attachment, } \\
\text { an index based on three } \\
\text { questions: how close ado- } \\
\text { lescents feel to their school, } \\
\text { how much a part of the } \\
\text { school they feel they are, } \\
\text { and how happy they are to } \\
\text { be at school (Chronbach } \\
\alpha=.78 \text { ) }\end{array}$ & 1.03 & .82 \\
\hline
\end{tabular}

\section{REFERENCES}

Allport, G. W. 1954. The Nature of Prejudice. Cambridge, Mass.: Addison-Wesley.

Aspin, L. T. 1988. "A Contextual Analysis of Power in Foreign Policy Behavior." Quality and Quantity 22:331-46.

Bearman, P. S., J. Moody, K. Stovel, and L. Thalji. In press. "Social and Sexual Networks: The National Longitudinal Study of Adolescent Health.” In Partnership Networks and the Spread of Infection, edited by Martina Morris. Oxford: Oxford University Press.

Billy, J. O., J. L. Rodgers, and J. R. Udry. 1984. "Adolescent Sexual Behavior and Friendship Choice." Social Forces 62:653-78.

Blalock, H. M. 1967. Toward a Theory of Minority-Group Relations. New York: Wiley.

Blau, P. M. 1977. Inequality and Heterogeneity: A Primitive Theory of Social Structure. New York: Free Press.

- 1994. Structural Contexts of Opportunities. Chicago: University of Chicago Press.

Blau, P. M., and J. E. Schwartz. 1984. Crosscutting Social Circles: Testing a Macrostructural Theory of Intergroup Relations. Orlando, Fla.: Academic Press.

Bossert, S. T. 1988-89. "Cooperative Activities in the Classroom." Pp. 225-50 in Review of Research in Education, vol. 15. Edited by E. Z. Rothkopf. Washington, D.C.: American Educational Association.

Breiger, R. L. 1974. "The Duality of Persons and Groups." Social Forces 53:181-90.

Charles, M., and D. B. Grusky. 1995. "Models for Describing the Underlying Structure of Sex Segregation." American Journal of Sociology 100:931-71.

Cohen, J., and P. Cohen. 1983. Applied Multiple Regression/Correlation Analysis for the Behavioral Sciences. Hillsdale, N.J.: Lawrence Erlbaum Associates.

Cohen, J. M. 1977. "Sources of Peer Group Homogeneity." Sociology of Education 50: 227-41.

_. 1983. "Peer Influence on College Aspirations." American Sociological Review 48:728-34.

Coleman, J. S. 1961. The Adolescent Society. New York: Free Press.

Coleman, J. S., and T. Hoffer. 1987. Public and Private High Schools: The Impact of Communities. New York: Basic Books.

Coleman, J. S., T. Hoffer, and S. Kilgore. 1982. "Achievement and Segregation in Secondary Schools: A Further Look at Public and Private School Differences." Sociology of Education 55:162-82. 


\section{American Journal of Sociology}

Cotterell, J. 1996. Social Networks and Social Influences in Adolescence. London: Routledge.

Crain, R. 1981. "Making Desegregation Work: Extracurricular Activities." Urban Review 12 (2): 121-27.

Davis, J. A. 1963. "Structural Balance, Mechanical Solidarity, and Interpersonal Relations." American Journal of Sociology 68:444-62.

Davis, J. A., and S. Leinhardt. 1972. "The Structure of Positive Relations in Small Groups.” Pp. 218-51 in Sociological Theories in Progress, vol. 2. Edited by J. Berger, M. Zelditch, and B. Anderson. Boston, Mass.: Houghton Mifflin.

DiPrete, T. A., and J. D. Forristal. 1994. "Multi-Level Models: Methods and Substance." Pp. 331-57 in Annual Review of Sociology, edited by John Hagan. Palo Alto, Calif.: Annual Reviews.

Doreian, P., R. Kapuscinski, D. Krackhardt, and J. Szczypula. 1996. "A Brief History of Balance through Time.” Journal of Mathematical Sociology 21 (1-2): 113-31.

Dunphy, D. C. 1963. "The Social Structure of Urban Adolescent Peer Groups." Sociometry 26:230-46.

Epstein, J. L. 1985. "After the Bus Arrives: Resegregation in Desegregated Schools." Journal of Social Issues 41:23-43.

Fararo, T. J., and J. Skvoretz. 1987. "Unification Research Programs: Integrating Two Structural Theories." American Journal of Sociology 92:1183-1209.

Feld, S. L. 1981. "The Focused Organization of Social Ties." American Journal of Sociology 86:1015-35.

Feld, S., and W. C. Carter. 1998. "When Desegregation Reduces Interracial Contact: A Class Size Paradox for Weak Ties." American Journal of Sociology 103:1165-86.

Frank, K. A., and J. Y. Yasumoto. 1998. "Linking Action to Social Structure within a System: Social Capital within and between Subgroups." American Journal of Sociology 104:642-86.

Freeman, L. C. 1972. "Segregation in Social Networks." Sociological Methods and Research 6:411-30.

Giles, M. W. 1978. "White Enrollment Stability and School Desegregation: A TwoLevel Analysis." American Sociological Review 43:848-64.

Granovetter, M. 1986. "The Micro-Structure of School Desegregation.” Pp. 81-110 in School Desegregation Research: New Directions in Situational Analysis, edited by Jeffrey Prager, Douglas Longshore, and Melvin Seeman. New York: Plenum Press.

Hallinan, M. T. 1978. "The Process of Friendship Formation." Social Networks $1: 193-210$

1 1982. "Classroom Racial Composition and Children's Friendships." Social Forces 61:56-72.

Hallinan, M. T., and W. N. Kubitschek. 1990. "The Formation of Intransitive Friendships." Social Forces 69 (2): 505-19.

Hallinan, M. T., and S. S. Smith. 1985. "The Effects of Classroom Racial Composition on Student's Interracial Friendliness." Social Psychological Quarterly 48:3-16.

Hallinan, M. T., and R. A. Teixeira. 1987. "Students' Interracial Friendships: Individual Characteristics, Structural Effects and Racial Differences." American Journal of Education 95:563-83.

Hallinan, M. T., and R. A. Williams. 1987. "The Stability of Students' Interracial Friendships.” American Sociological Review 52:653-64.

- 1989. "Interracial Friendship Choices in Secondary Schools." American Sociological Review 54:67-78.

Heider, F. 1946. "Attitudes and Cognitive Organization." Journal of Psychology 21: $107-12$.

Hewstone, M., and R. Brown. 1986. Contact and Conflict in Encounters. Oxford: Basil Blackwell.

Holland, A., and T. Andre. 1987. "Participation in Extracurricular Activities in 
Secondary School: What Is Known, What Needs to Be Known." Review of Educational Research 57:437-66.

Holland, P. W., and S. Leinhardt. 1971. "Transitivity in Structural Models of Small Groups." Comparative Groups Studies 2:107-24.

Iversen, G. R. 1991. Contextual Analysis. Beverly Hills, Calif.: Sage.

Johnsen, E. C. 1985. "Network Macrostructure Models for the Davis-Leinhardt Set of Empirical Sociomatrices." Social Networks 7:203-24.

Johnson, D. W., and R. T. Johnson. 1992. "Positive Interdependence: Key to Effective Cooperation." Pp. 174-99 in Interaction in Cooperative Groups, edited by R. HertzLazarowitz and N. Miller. Cambridge: Cambridge University Press.

Kandel, D. B. 1978. "Homophily, Selection, and Socialization in Adolescent Friendships." American Journal of Sociology 84:427-36.

Kennedy, P. 1992. A Guide to Econometrics. Cambridge, Mass.: MIT Press.

Lee, V. E., T. K. ChowHoy, D. T. Burkam, D. Geverdt, and B. A. Smerdon. 1998. "Sector Differences in High School Course Taking: A Private School or Catholic School Effect?" Sociology of Education 71:314-35.

Lincoln, J. R. 1984. "Analyzing Relations in Dyads." Sociological Methods and Research 13:45-76.

Longshore, D., and J. Prager. 1985. "The Impact of School Desegregation: A Situational Analysis." Annual Review of Sociology 11:75-81.

MacLeod, J. 1995. Ain't No Making It: Aspirations and Attainment in a Low Income Neighborhood. Boulder, Colo.: Westview Press.

Marsden, P. V. 1990. "Network Data and Measurement." Annual Review of Sociology $16: 435-63$

McPherson, J. M., and L. Smith-Lovin. 1987. "Homophily in Voluntary Organizations: Status Distance and the Composition of Face to Face Groups." American Sociological Review 52:370-79.

Mosteller, F. 1968. "Association and Estimation in Contingency Tables." Journal of the American Statistical Association 63:1-28.

Newcomb, T. M. 1961. The Acquaintance Process. New York: Holt, Rinehart \& Winston.

Orfield, G. 1996. Dismantling Desegregation: The Quiet Reversal of Brown V. Board of Education. New York: New Press.

Orfield, G., M. D. Bachmeier, D. R. James, and T. Eitle. 1997. "Deepening Segregation in American Public Schools: A Special Report from the Harvard Project on School Desegregation." Equity and Excellence in Education 30:5-24.

Patchen, M. 1982. Black-White Contact in Schools. West Lafayette, Ind.: Purdue University Press.

Pattison, P., and S. Wasserman. 1999. "Logit Models and Logistic Regression for Social Networks: II. Multivariate Relations." British Journal of Mathematical and Statistical Psychology 52:169-93.

Quiroz, P. A., N. F. Gonzalez, and K. A. Frank. 1996. "Carving a Niche in the High School Social Structure: Formal and Informal Constraints on Participation in the Extracurriculum.” Research in Sociology of Education 11:93-120.

Rytina, S., and D. Morgan. 1982. "The Arithmetic of Social Relations: The Interplay of Category and Network." American Journal of Sociology 88:88-113.

Sandy, J. 1989. "The Choice of Public or Private School." Social Science Journal 26: 415-31.

Schofield, J. W. 1979. "The Impact of Positively Structured Contact on Intergroup Behavior: Does It Last under Adverse Conditions?” Social Psychological Quarterly 42:280-84.

- 1991. "School Desegregation and Intergroup Relations: A Review of the Literature." Review of Research in Education 17:335-409.

. 1995. "Improving Intergroup Relations among Students." Pp. 635-46 in 


\section{American Journal of Sociology}

Handbook of Research on Multicultural Education, edited by J. A. Banks and C. A. M. Banks. New York: Macmillan.

Slavin, R. E., and N. A. Madden. 1979. "School Practices That Improve Race Relations." American Educational Research Journal 16:169-80.

Smith, A. W. 1981. "Racial Tolerance as a Function of Group Position." American Sociological Review 46:558-73.

St. John, N. H., and R. G. Lewis. 1975. "Race and the Social Structure of the Elementary Classroom." Sociology of Education 48:346-68.

Stockard, J., and M. Mayberry. 1992. Effective Educational Environments. Newbury Park, Calif.: Corwin Press.

Stolzenberg, R. M., and D. A. Relles. 1997. "Tools for Intuition about Sample Selection Bias and Its Correction." American Journal of Sociology 62:494-507.

Taueber, K. E., and D. R. James. 1982. "Racial Segregation among Public and Private Schools." Sociology of Education 55:133-43.

Tuma, N. B., and M. T. Hallinan. 1979. "The Effects of Sex, Race, and Achievement on School Children's Friendships." Social Forces 571 (4): 1265-85.

van der Poel, M. 1993. Personal Networks. Netherlands: Swets \& B. V. Zeitlinger.

Verbrugge, L. M. 1977. "The Structure of Adult Friendship Choices." Social Forces 56:576-97.

Wasserman, S., and K. Faust. 1994. Social Network Analysis. Cambridge: Cambridge University Press.

Wasserman, S., and P. Pattison. 1996. "Logit Models and Logistic Regressions for Social Networks: I. An Introduction to Markov Graphs and P*." Psychometrika 61:401-25.

Willis, P. E. 1977. Learning to Labor: How Working Class Kids Get Working Class Jobs. New York: Columbia University Press.

Winship, C., and R. Mare. 1992. "Models for Sample Selection Bias." Annual Review of Sociology 18:327-50.

Zeggelink, E. P. H. 1993. Strangers into Friends: The Evolution of Friendship Networks Using an Individual Oriented Modeling Approach. Amsterdam: ICS. 